\title{
The graveyard economy
}

\author{
Ho Manh Toan \\ Phenikaa University

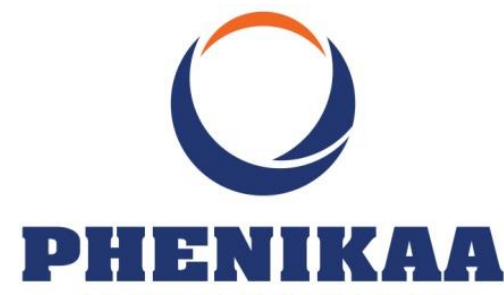

U N I VER S I T Y

Hanoi, Vietnam

January 26, 2021

When I was in Japan, I mostly went to the supermarket for shopping. They are well-lit, can be found easily, and the foods are always fresh. Occasionally, I went to the Beppu Station Market, located in a tunnel under the town's train track. Hence, it is popular among Vietnamese with the name: Chơ gầm cầu (literally, the under-bridge market).

Even though it is called a market, Chợ gầm cầu is still cleaner and more organized than many Vietnam markets. Despite the marvel economic achievement in recent years [1,2], Vietnam is still famous for its earthly atmosphere, with motorbikes and noisy street vendors. In Vietnam, even though the GDP per capita was only around US $\$ 2,700$ in 2019, luxury cars like Mercedes-Benz, Lexus, or Porsche are still selling excellently [3]. The mindset is not entirely new. The spending spree of Vietnamese has been observed by many economists [4]. Indeed, they are the driver of the stable growth rate, even during the COVID-19 period [5].

However, there is another angle that is often overlooked. Here, I would like to call it: the graveyard economy, which you can see in Figure 1. 
Figure 1. The graveyard economy

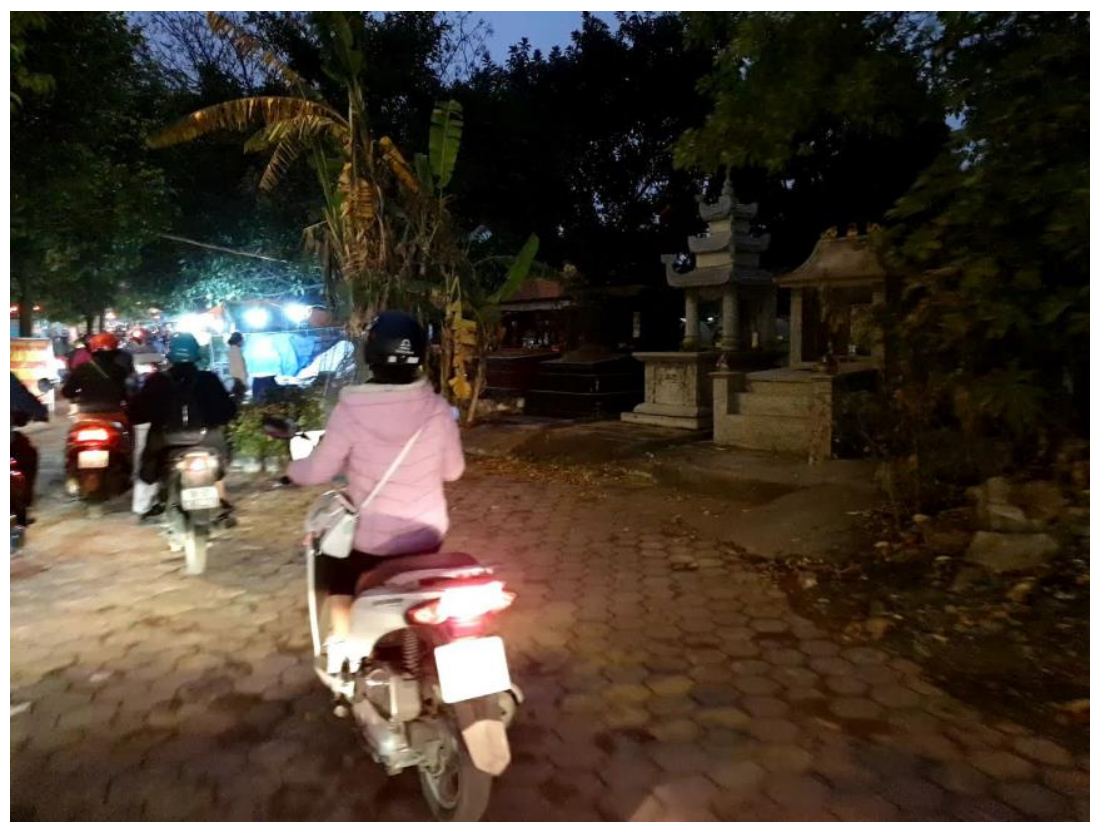

Please forgive me for the quality of the pictures. They were taken when I was riding on the pavement to avoid the traffic jam. However, you can still see, next to where our ancestors rest, life is thriving. This small vendor is selling kumquat trees for the Têt holiday. Going along the pavement, you have abundant selections for your lovely home during the Têt holiday (Figure 2-5).

Figure 2. How about some shelves and artworks?

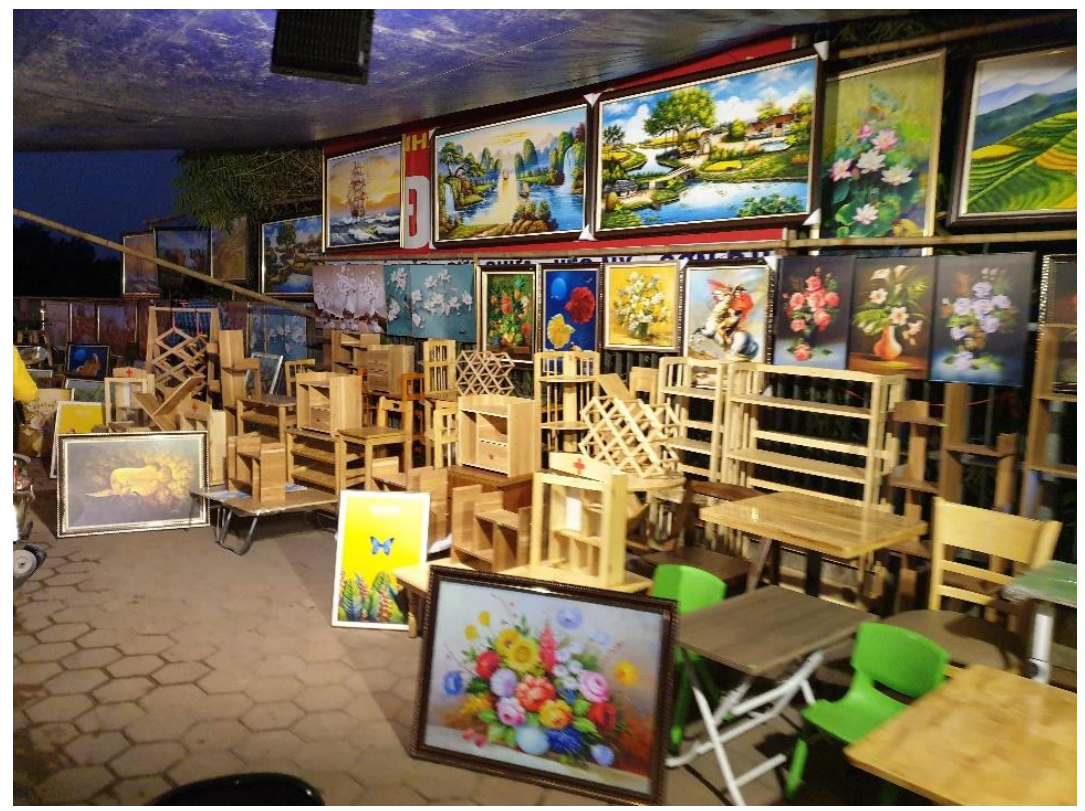


Figure 3. Playful toys for your children can be found here.

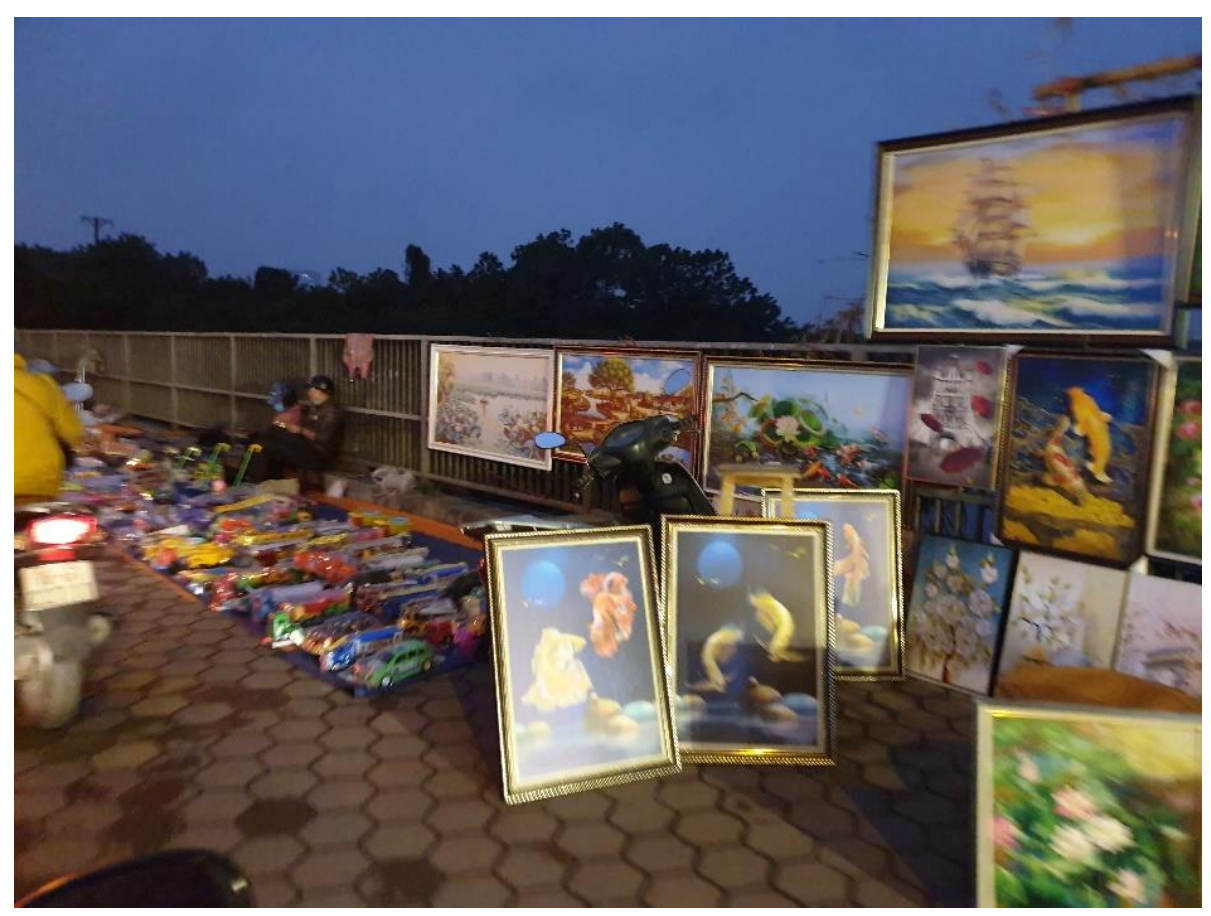

Figure 4. Suitcases for traveling and new mattresses for your lively living room?

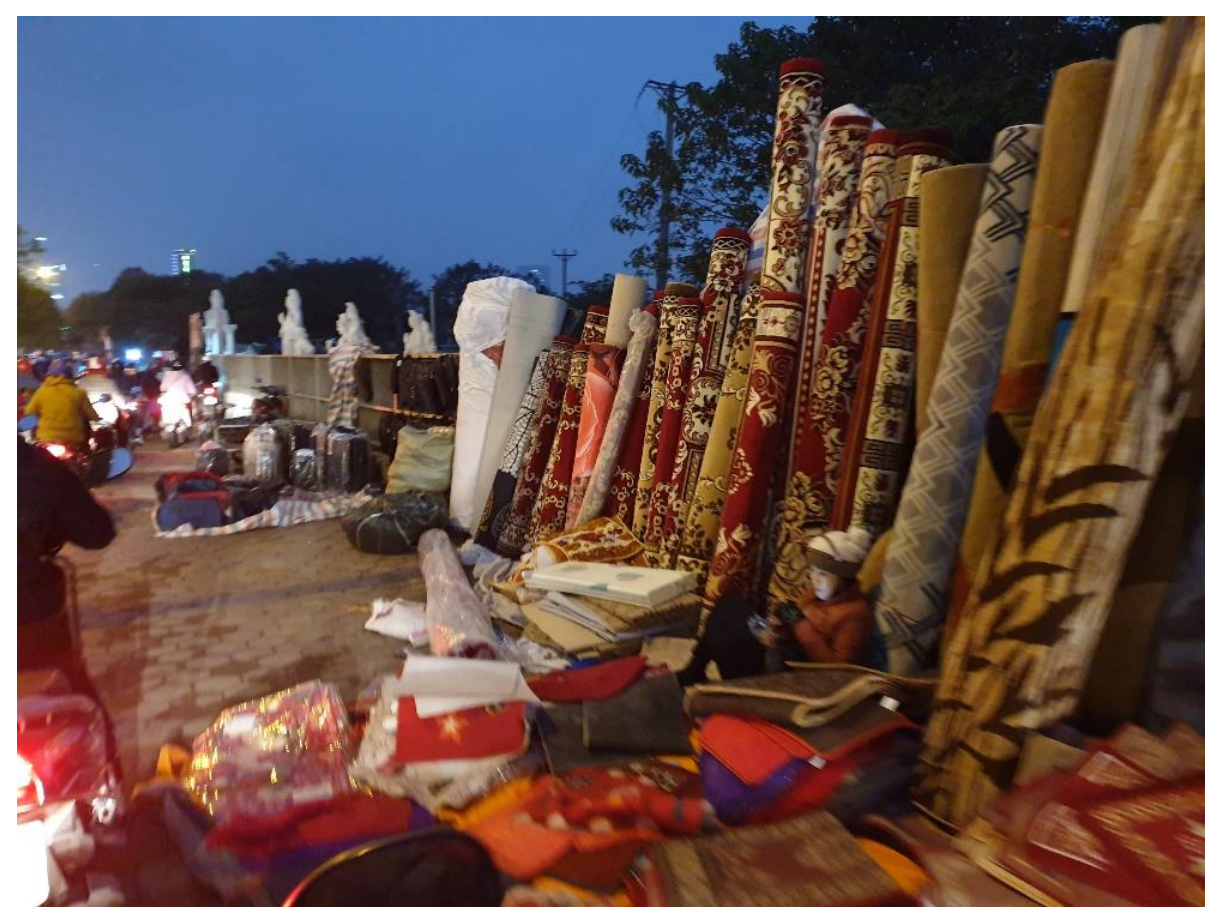


Figure 5. A new pair of shoes for Têt?

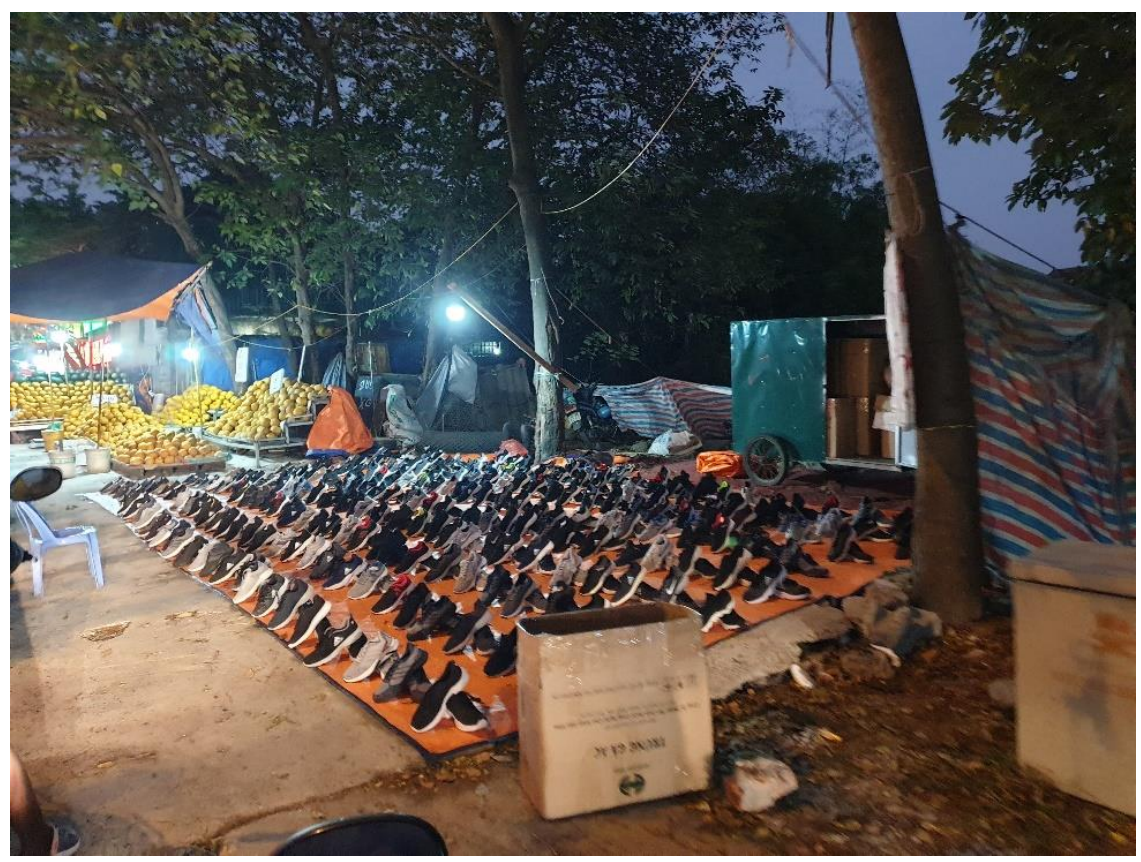

I understand that it is hard for you to imagine the scenario, but this happens in Vietnam daily. On one side, the supercars flood the road, thus leaving no space for the motorbikes. On the other side, motorbikes climb up the pavement, leisurely pass through the vendors, and quickly shop for what they need.

It is messy and noisy, but it is also lively.

The spontaneity of these roadside markets can be attributed to the complex cultural additivity in Vietnam [6,7]. The roadside is a good destination for business. They increase the visibility of the shop. Thus, regardless of the crude condition, and especially the spirituality, in this case, people still do what they need to do. The customers also accept the market easily. The value of convenience enters their mindsets through the mindsponge mechanism $[8,9]$ and continues to remain a core value.

When will the graveyard economy be replaced by the standard supermarket and other modern formats?

In a country full of paradoxes, the juxtaposition between the liveliness of the living next to the land of the death continues to make us ponder. 
Note: Photo credits go to Minh-Hoang Nguyen (ORCID: https://orcid.org/00000002-7520-3844). Thank you for taking the photos in such a bumpy condition.

\section{References}

[1] Chính, P. M., \& Hoàng, V. Q. (2009). Kinh tế Việt Nam: Thăng trầm và đột phá. Nxb Chính trị Quốc gia, Hà Nội.

[2] Chính, P. M., \& Hoàng, V. Q. (2008). Bối cảnh tài chính Việt Nam 1997-1998 và 2007-2008: Khoảng cách và biến đối. Nghiên cứu Kinh tế, 48(7), 3-24.

[3] Huy, D. (2020). Drivers more geared towards luxury cars. VnExpress International. Retrieved from https://e.vnexpress.net/news/business/ industries/drivers-more-geared-towards-luxury-cars-4042211.html

[4] Vuong, Q. H. (2011). Vietnam's Underground Economy: Where "Sharks" Were Food. Stratfor Global Intelligence. Retrieved from https://worldview.stratfor.com/article/vietnams-underground-economywhere-sharks-were-food

[5] La, V. P., et al. (2020). Policy Response, Social Media and Science Journalism for the Sustainability of the Public Health System Amid the COVID-19 Outbreak: The Vietnam Lessons. Sustainability, 12(7), 2931.

[6] Vuong, Q. H., et al. (2020). On how religions could accidentally incite lies and violence: Folktales as a cultural transmitter. Palgrave Communications, 6, 82.

[7] Vuong, Q. H., et al. (2018). Cultural additivity: Behavioural insights from the interaction of Confucianism, Buddhism, and Taoism in folktales. Palgrave Communications, 4, 143.

[8] Vuong, Q. H., \& Napier, N. K. (2015). Acculturation and global mindsponge: an emerging market perspective. International Journal of Intercultural Relations, 49, 354-367.

[9] Vuong, Q. H. (2016). Global mindset as the integration of emerging sociocultural values through mindsponge processes: A transition economy perspective. In J. Kuada (ed.) Global Mindsets: Exploration and Perspectives (pp. 109-126). London: Routledge. 